\title{
IDENTIFIKASI FAKTOR TRANSFORMASI HUNIAN PADA PERUMAHAN JOHOR INDAH PERMAI MEDAN
}

\author{
Devy N. Syahri ${ }^{1}$, Waginah $^{2}$, Dwira Nirfalini Aulia ${ }^{3}$ \\ Departemen Arsitektur Fakultas Teknik Universitas Sumatera Utara \\ Jl. Perpustakaan St. J07 Building, Medan, 20155, Indonesia \\ *Email: ${ }^{1}$ devynofita@gmail.com, ${ }^{2}$ waginahwaw1@gmail.com, ${ }^{3}$ dwira_aulia@yahoo.com
}

\begin{abstract}
ABSTRAK
Seiring dengan pemahaman akan rumah layak huni, rumah sebagai lingkkungan terdekat manusia harus memenuhi syarat layyak huni dimana penghuni dapat melakukan kegiatannya secara aman, nyaman, dan sesuai kebutuhan. Pada dasarnya perumahan terencana sudah dibangun dengan bentuk yang sama dan teratur, namun pada perumahan Johor Indah Permai sebagian besar penghuni telah melakukan perubahan pada rumahnya saat ditempati. Perubahan tersebut dapat mengindikasikan adanya kekurangan/ketidakpuasan penghuni terhadap rancangan rumah yang disediakan karena perbedaan karakter dari setiap penghuni. Tujuan dari penelitian ini adalah untuk mengetahui proses transformasi fisik dan non fisik pada perumahan tersebut, mengetahui faktor-faktor penyebab perubahan, dan utnuk mengetahui adanya kearifan lokal pada faktor-faktor tersebut. Metode penelitian dilakukan dengan studi literatur dan survei lapangan. Survei lapangan meliputi pengamatan, wawancara dan observasi langsung terhadap delapan penghuni rumah di perumahan tersebut. Hasil penelitian ini menunjukkan bahwa adanya pertambahan kebutuhan yang disebabkan oleh pertumbuhan keluarga atau pertambahan saudara, serta status pendidikan penghuni yang relatif tinggi mempengaruhi tingat pendapatan ang mendorong dan memicu penghuni dalam melakukan perubahan ruang untuk mencerminkan jati diri penghuni yang ingin memiliki rumah yang berbeda dari rumah sekitarnya.
\end{abstract}

Kata Kunci: faktor transformasi hunian, perumahan terencana.

\section{PENDAHULUAN}

Rumah sebagai lingkungan terdekat manusia harus memenuhi syarat layak huni karena merupakan ruang dimana manusia dapat melakukan kegiatan didalamnya (Badudu,1990). Keseragaman bentuk rumah yang dikembangkan oleh developer, tidak bisa mewadahi perilaku penghuni untuk proses adaptasi atau merubah lingkungannya. (Van-de-Ven,1995), menjelaskan bahwa menciptakan ruang haruslah dengan cara yang benar-benar direncanakan dan dipikirkan dengan baik. Perumahan kebanyakan telah kehilangan makna awal sebagai wadah kebutuhan akan rumah tinggal karena di bangun mendesak dan dalam jumlah yang banyak, serta didukung oleh revolusi industri. Akibatnya kebutuhan dan nilai-nilai budaya masyarakat kurang diperhatikan. Maka dari itu pemilihan lingkungan perumahan diharapkan mampu memberi perbandingan keadaan dengan perumahan-perumahan di Indonesia pada umumnya (Salura, 2001).

Perubahan fisik rumah banyak di pengaruhi oleh faktor antara lain, adanya pertambahan kebutuhan yang di sebabkan oleh pertumbuhan keluarga atau pertambahan sanak keluarga yang menumpang tinggal, sebagai cerminan jati diri karena keinginan penghuni untuk memiliki rumah yang berbeda dengan rumah disekitarnya serta budaya dan lingkungan dimana manusia itu tinggal. Mengacu pada karya psikolog ekologi Roger Beker. Sasaran dari perancangan arsitektural adalah menciptakan bentuk yang memuaskan perilaku. Ketepatan suatu bentuk tergantung pada sejauh mana ia cocok dengan konteks perilaku, sosial dan budayanya (Snyder et al., 1991).

\section{TUJUAN PENELITIAN} berikut:

Tujuan dari penelitian ini adalah sebagai

Edisi cetak 
1. Untuk mengetahui proses transformasi fisik dan non fisik pada perumahan Johor Indah permai Medan;

2. Untuk mengetahui faktor-faktor penyebab perubahan tersebut;

3. Untuk mengetahui adanya kearifan lokal pada faktor-faktor tersebut.

\section{LANDASAN TEORI}

\section{Pengertian Rumah/Perumahan}

Rumah Tinggal bukan hanya bangunan yang bersifat fisik, namun juga sebagai tempat berlindung bersama keluarga. Keberadaan penghuni didalamnya akan menciptakan ruang yang diperlukan dan lingkungan di sekitarnya. Silas (1983) mengatakan rumah atau perumahan sebagai suatu proses berkembang sesuai dengan kehendak, kemampuan dan peluang yang ada setiap saat sejalan dengan pertumbuhan/ perkembangan biologis, sosial dan ekonomi keluarga bersangkutan. Soebroto (1983) mengatakan bahwa rumah juga sebagai tempat berlangsung proses sosialisasi, proses dimana seorang individu diperkenalkan kepada nilai, adat kebiasaan berlaku dalam masyarakatnya, dengan demikian bisa terjadi bahwa pola pemakaian ruang merupakan cermin dari nilai budaya.

\section{Transformasi Hunian}

Menurut Makachia (2011) perubahan perumahan menceritakan nilai-nilai penghuni disesuaikan dengan tujuan ekonomi, sosial dan fisik, perubahan yang tidak diperhitungkan dengan baik yang mengabaikan kebutuhan fungsional dasar dapat berdampak pada kondisi fisik dan sosial perumahan. Seperti yang dikatakan oleh Shiferaw (1998) kontrol yang ketat dari pemerintah mengenai ekstensi dan modifikasi perumahan ternyata tidak berhasil karena banyaknya pelanggaran, tetapi dibalik itu ternyata bahwa cara penghuni melakukan trasformasi perumahan merupakan petunjuk untuk perencanaan pembangunan perumahan di masa mendatang dengan melihat perubahan saat ini.

Perubahan fisik rumah banyak di pengaruhi oleh faktor antara lain, adanya pertambahan kebutuhan yang di sebabkan oleh pertumbuhan keluarga atau pertambahan sanak keluarga yang menumpang tinggal, sebagai cerminan jati diri karena keinginan penghuni untuk memiliki rumah yang berbeda dengan rumah disekitarnya serta budaya dan lingkungan dimana manusia itu tinggal. Mengacu pada karya psikolog ekologi Roger Beker. Sasaran dari perancangan arsitektural adalah menciptakan bentuk yang memuaskan perilaku. Ketepatan suatu bentuk tergantung pada sejauh mana ia cocok dengan konteks perilaku, sosial dan budayanya (Snyder et al., 1991). Perletakan tata ruang turut mempengaruhi perilaku penghuninya terutama mengenai privasi, maka akan terjadi respon oleh penghuni untuk menjaga privasidengan mengadaptasi rumah tinggalnya. (Taufikurahman, 2010).

Perubahan rumah adalah upaya penghuni untuk memperbaiki atau mengubah bentuk rumahnya berdasarkan keinginan serta kebutuhannya, perubahan yang dilakukan pada aspek fisik memperlihatkan kemampuan dan kapasitas penghuni dalam melakukan perubahan rumah (Sjaifoel, 2009). Seperti dikemukakan Raharjo (2010) ada dua usaha yang dapat dilakukan penghuni terhadap rumahnya, yaitu Pertama, usaha memenuhi kebutuhan ketika penghuni merasakan kekurangan pada rumahnya. Bentuk tindakan dapat berupa pindah rumah, juga dapat berupa pengubahan atau penambahan terhadap rumahnya. Jadi penghuni secara aktif menimbulkan perubahan terhadap keadaan rumahnya atau diistilahkan sebagai housing adjustment. Kedua, Usaha penghuni sebagai tanggapan atas tekanan akibat berbagai kekurangan pada rumah, dengan cara melakukan perubahan pada dirinya tanpa merubah rumahnya. Dalam hal ini penghuni bersifat pasif atau diistilahkan sebagai housing adaptation.

Sabarudin, dkk. (2003) mengatakan bahwa perubahan rumah didorong oleh sifat manusia yang selalu ingin dan berupaya mengungkap jati dirinya. Perubahan rumah ini juga dapat memicu perubahan perumahan karena ruang yang disediakan cukup terbatas sedangkan jumlah anggota keluarga semakin bertambah dan membutuhkan ruang tambahan. Perubahan yang diakibatkan oleh perubahan rumah dapat menimbulkan masalah baik secara sosial, ekonomi dan lingkungannya.

\section{METODE PENELITIAN}

Metode yang digunakan adalah deskriptif kualitatif dengan melihat berbagai sumber penelitian perubahan pada perumahan. Pengumpulan data dilakukan dengan cara melakukan observasi, wawancara, dan melihat berbagai sumber pustaka. Studi literatur 
dilakukan dengan telaah teori yang berkaitan dengan perubahan rumah tinggal dan faktorfaktor yang mendukung terjadinya perubahan. Pengamatan obyek studi dilakukan dengan cara mengamati kkondisi saat ini, membuat rekaman gambar dengan sketsa yang kemudian digambar ulang dengan software Sketchup, dan membuat dokumentasi foto.

Wawancara dilakukan dengan memilih responden yang dapat memberikan informasi yang sesuai dengan permasalahan penelitian atau menarik sampel secara sengaja (purposive sampling). Tahap analisis dilakukan dengan membandingkan kondisi awal dan kondisi saat ini. Analisis ini berlanjut dengan tahap menemukan penyebab perubahan desain pada perumahan tersebut.

Penarikan kesimpulan dilakukan dengan mencari variabel terbanyak yang menjadi ppenyebab terjadinya perubahan pada rumah tinggal saat ditempati di Perumahan Johor Indah Permai, Medan, dan kaitan faktor penyebab perubahannya dengan kearifan lokal.

Pada akhirnya analisis teersebut diharapkan mampu menghasilkan sebuah kesimpulan yang kemudian menjadi jawaban atas permasalahan yang diteliti.

Perumahan ini sudah dihuni selama hampir 30 tahun dan sudah banyak terjadi transformasi hunian disana. Populasi dalam penelitian ini adalah seluruh unit rumah yang lebih banyak mengalami perubahan fisik maupun non fisik. Penentuan sampel dengan penunjukkan langsung di lapangan (purposive sampling) ditetapkan 8 unit rumah.

Variabel penelitian ini dibagi menjadi dua, yaitu variabel fisik dan variabel non fisik. Variabel fisik, meliputi; tata letak ruang (perubahan ruang dan pembatas ruang), jumlah anggota keluarga, visualisasi bangunan, dan penambahan ruang. variabel non fisik, meliputi; kondisi sosial, budaya, dan kondisi ekonomi (penghasilan).

\section{HASIL DAN PEMBAHASAN}

Penelitian ini lebih menekankan pada pengamatan atau kajian terhadap perubahan desain awal rumah yang berkaitan dengan unsur-unsur arsitektural ang bersifat fisik, maupun non fisik, sehingga lebih mudah untuk melakukan pengamatan terhadap perubahan desain yang terjadi dan menemukan faktor penyebab perubahan tersebut. Tabel 1 memperlihatkan data perubahan yang terjadi dengan membandingkan desain awal dan kondisi rumah setelah ditempati penghuni pada delapan rumah yang berbeda.

Tabel 1. Desain Awal dan Kondisi Rumah Setelah Ditempat

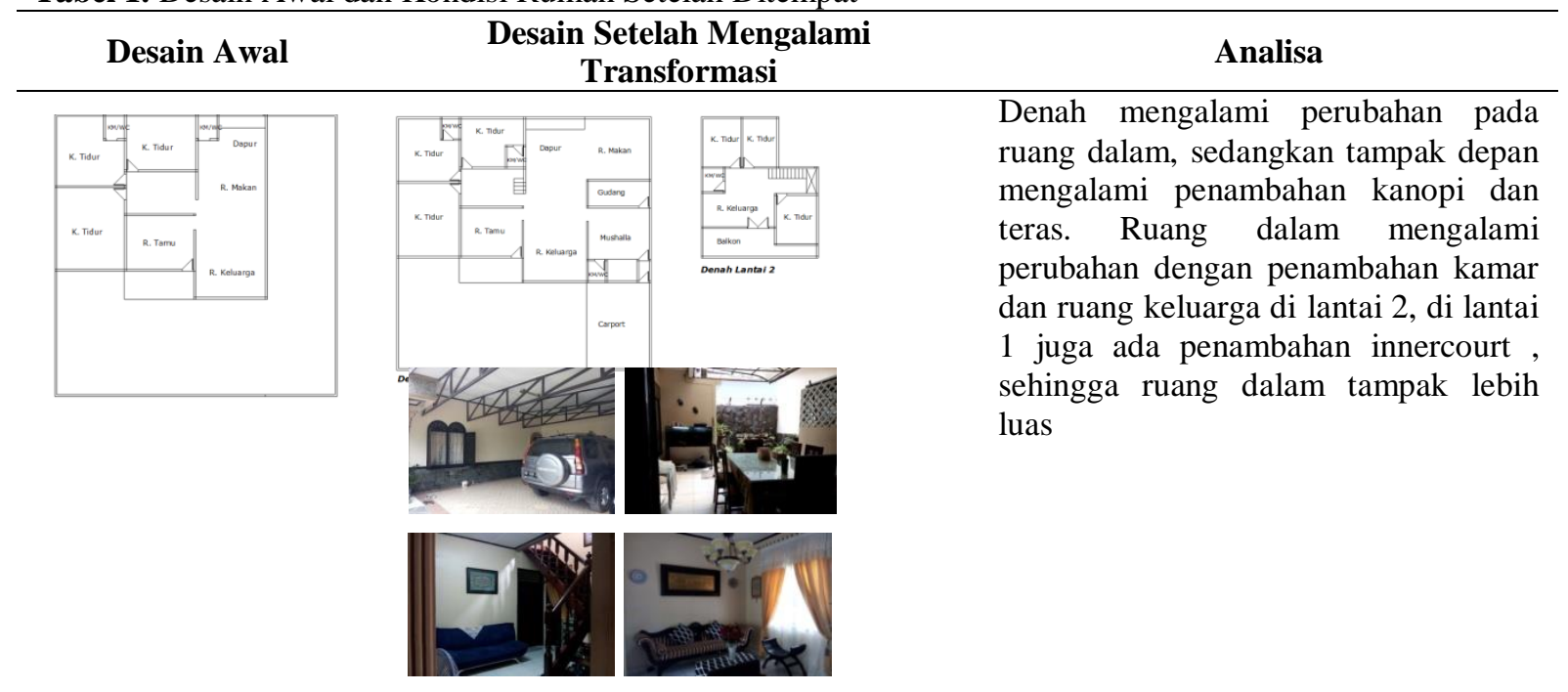




\begin{tabular}{ll}
\hline \multicolumn{3}{c}{$\begin{array}{c}\text { Desain Setelah Mengalami } \\
\text { Transformasi }\end{array}$} & \multicolumn{1}{c}{ Analisa } \\
\hline
\end{tabular}

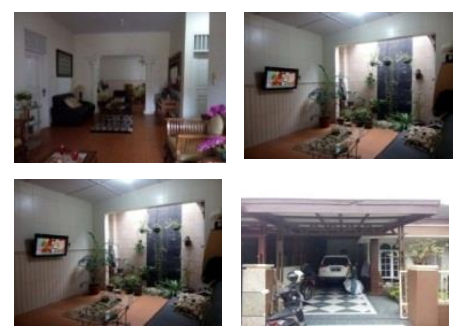

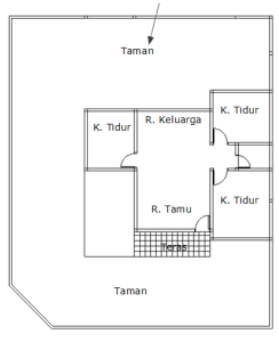
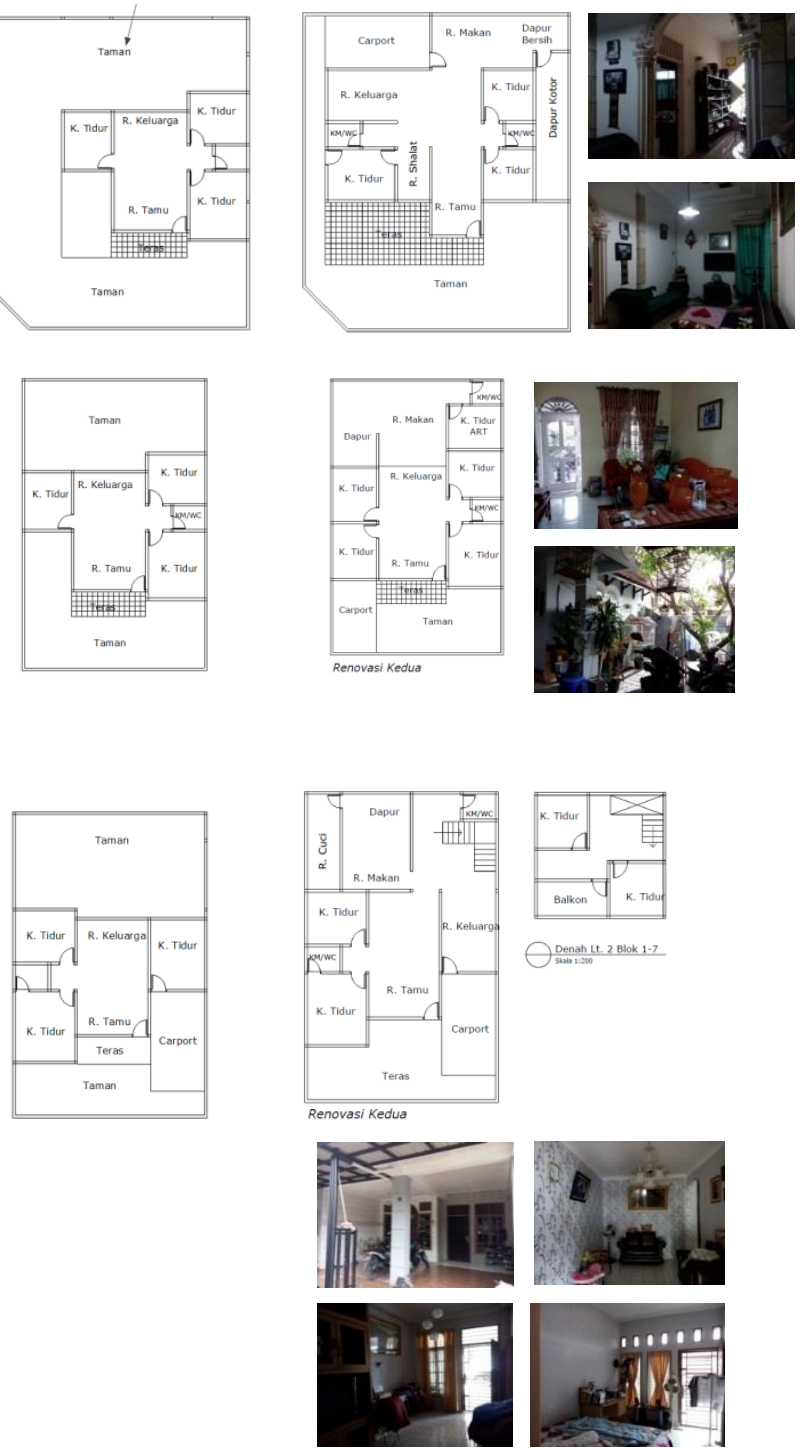

Denah mengalami perubahan dan sisa tanah disisi rumah, sedangkan tampak depan mengalami perubahan kanopi dan pintu masuk menuju ruang makan, ruang dalam mengalami perubahan dengan penambahan ruang makan disisi rumah, ruang sholat dan perluasan ruang keluarga.

Denah mengalami perubahan dan sisa tanah disisi bagian belakang rumah, sedangkan tampak depan mengalami perubahan dengan menambah kamar disisi rumah, dapur ruang makan, kamar asisten rumah tangga dan kamar mandi di bagian belakang ruamah.

Denah mengalami perubahan dan penambahan lantai 2, sedangkan tampak depan mengalami perubahan dengan menambah teras. Ruang dalam mengalami perubahan dengan menambah kamar di sisi rumah, ruang keluarga, dapur, ruang cuci, kamar mandi dan penambahan lantai 2 berupa kamar dan balkon 


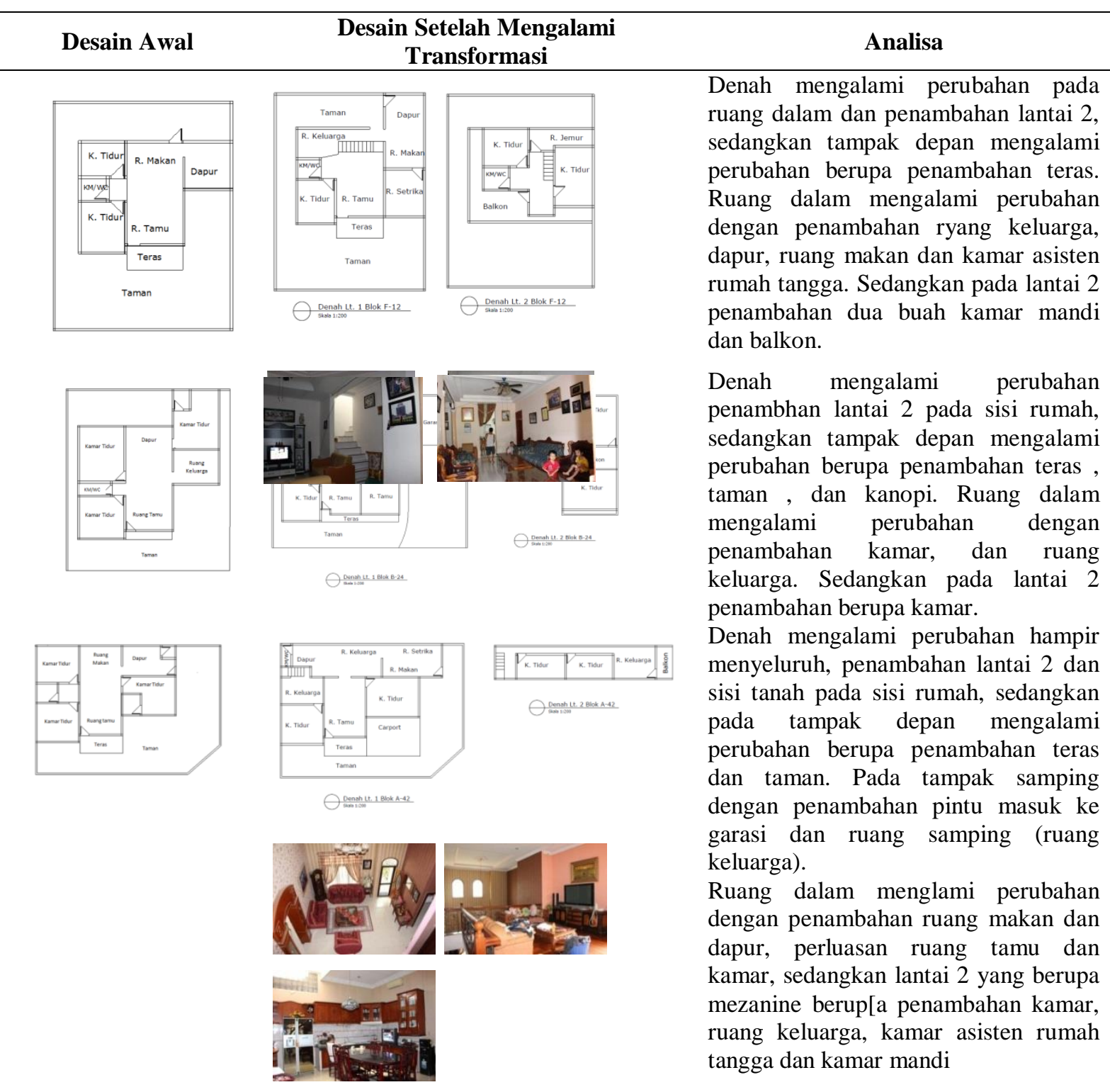

Dari Tabel 1 dapat dilihat bahwa tingkat perubahan pada sampel Perumahan Johor Indah Permai digolongkan menjadi tiga, yaitu perubahan sebagian kecil, sebagian besar, dan keseluruhan.

Pada perubahan sebagian kecil, rata-rata penghuni hanya melakukan perubahan di beberapa ruangan saja, seperti ruang keluarga, dapur, dan ruang makan, serta menambahkan kanopi pada carport.

Pada perubahan sebagian besar, beberapa rumah yang memiliki halaman di bagian belakang memanfaatkan area tersebut untuk menambah ruang yang dapat memperluas denah rumah dan melakukan perubahan pada beberapa ruang, seperti kamar tidur, ruang keluarga, dapur, ruang makan, dan garasi, serta menambah lantai 2.

Pada perubahan keseluruhan, penghuni merubah hampir seluruh denah rumah dan juga menambahkan beberapa ruang. Untuk kepentingan itu, penghuni menambahkan lantai 2 pada rumahnya.

Berdasarkan hasil survey yang dilakukan, diperoleh beberapa faktor yang menyebabkan penghuni melakukan perubahan pada rumahnya, yaitu:

1. Faktor kearifan lokal;

2. Fator gaya hidup;

3. Faktor jumlah penghuni;

4. Faktor respon lingkungan. 
Hal ini sesuai dengan hasil penelitian yang ditulis oleh D. Stevanus, A. Thahir dan Indartoyo.

Pada rumah blok B-4 tipe 45 penghuni melakukan renovasi dan penambahan fungsi pada ruang keluarga yang disebabkan karena penghuni suka berkumpul dengan sesama anggota keluarga dan sanak saudara. Penghuni juga menambahkan dua buah kamar tidur karena bertambahnya jumlah penghuni yang menetap di rumah tersebut. Selain itu, penghuni juga menambahkan balkon pada lantai 2 sebagai respon terhadap lingkungan, yaitu agar dapat menikmati pemandangan dari lantai 2. Pada rumah tersebut, penghuni juga menambahkan mushalla yang mencerminkan gaya hidup dari penghuni tersebut agar tetap bisa melaukan ibadah dengan nyaman.

Pada rumah blok C-16 tipe 74 penghuni melakukan perluasan pada ruang makan karena penghuni merasa membutuhkan ruang khusus untuk makan bersama keluarga. Selain itu penghuni juga melakukan penambahan pada ruang keluarga, innercourt dan melakukan relokasi posisi dapur karena penghuni merasa lebih nyaman apabila dapur berada di dalam. Hal ini mencerminkan gaya hidup dari penghuni rumah tersebut.

Pada rumah blok B-25 tipe 65 penghuni melaukan hal yang sama dengan pemilik rumah blok B-4 tipe 45, yaitu menambahkan mushalla pada rumahnya sebagai bentuk gaya hidup dari penghuni rumah tersebut. Penghuni juga melakukan relokasi ruang keluarga arena merasa bahwa ruang keluarga tidak boleh terlihat dari ruang tamu.

Pada rumah blok C-51 tipe 65 penghuni melakukan perubahan denah dengan menambahkan beberapa ruang, yaitu ruang kamar tidur untuk pembantu, penambahan ruang makan karena penghuni merasa perlunya ruang khusus bagi keluarga untuk makan bersama, dan menambahkan kamar tidur anak karena pertumbuhan anak yang mengharuskan untuk memisahkan kamar anak perempuan dan anak laki-laki.

Hal yang tak jauh berbeda juga dilakukan pada beberapa rumah lainnya di Perumahan Johor Indah Permai Medan.

\section{KESIMPULAN}

Dapat disimpulkan bahwa faktor transformasi hunian pada Perumahan Johor Indah Permai, adalah:
1. Faktor kearifan lokal;

2. Fator gaya hidup;

3. Faktor jumlah penghuni;

4. Faktor respon lingkungan.

Mayoritas penghuni pernah melakukan perubahan fisik ruang dalam pada rumah mereka. Untuk kategori jenis ruang yang pernah mengalami perubahan, mayoritas perubahan dilakukan pada dapur, ruang makan, dan ruang keluarga. Ini menunjukkan bahwa ruang-ruang tersebut membutuhkan desain khusus yang berbeda bagi setiap penghuni.

Tingkat perubahan yang dilakukan oleh penghuni rumah pada Perumahan Johor Indah Permain dibedakan menjadi tiga, yaitu:

1. Perubahan sebagian kecil;

2. Perubahan sebagian besar;

3. Perubahan keseluruhan.

\section{Daftar Pustaka}

Badudu (1990) Kamus Besar Bahasa Indonesia.

Stevanus, D., dkk. (2015) StudiPerubahan Fungsi Ruang Pada Unit Rumah Tinggal Di Cluster Orlando Dan Georgia, Kota Wisata Cibubur. AGORA, Jurnal Arsitektur, Volume 15 nomor 1 Juni 2015.

Makachia, P. A. (2011) Evolution of urban housing strategies and dweller-initiated transformations in Nairobi. City, Culture and Society, 2(4), 219-234.

Raharjo, N. P. (2010) Dinamika Pemenuhan Kebutuhan Perumahan Masyarakat Berpenghasilan Rendah. UNIVERSITAS DIPONEGORO.

Sabarudin, A., dkk. (2003) Perkembangan Perumahan Rakyat Masa Lalu, Saat ini, dan Masa Mendatang: Jakarta: Badan Penerbit Puskim.

Salura (2001) ber-Arsitektur: Membuat,
Menggunakan, Mengalami dan
Memahami.

Shiferaw, D. (1998) Self-initiated transformations of public-provided dwellings in Addis Ababa, Ethiopia. Cities, 15(6), 437-448. 
Silas.J., (1983) Beberapa Pemikiran Dasar Tentang Perumahan dan Perkampungan di Indonesia. Makalah dalam diskusi Ilmiah mahasiswa Arsitektur Indonesia di Bandung.

Sjaifoel, E. (2009) Kajian Perubahan Fisik Rumah Tinggal pada Permukiman Perumnas Martubung Medan. Program Pascasarjana USU: Medan.

Snyder, et al., (1991) Pengantar Arsitektur. Erlangga, Jakarta. Soebroto.P.E., 1983. Aspek Aspek Sosial Phikologis pada Pemukiman Masyarakat berpengasilan Rendah di kota kota besar. Makalah pada seminar Habitat Nasional. Ikatan Arsitek Indonesia (IAI) Edisi Maret 1983.

Soebroto.P.E., (1983) Aspek-aspek Sosial Phikologis pada Pemukiman Masyarakat berpengasilan Rendah di kota kota besar. Makalah pada seminar Habitat Nasional. Ikatan Arsitek Indonesia (IAI) Edisi Maret 1983.

Taufikurahman (2010) Perubahan Pola Tatanan Rumah Tinggal Sebagai Akibat Kegiatan Industri Rumah Tangga (Studi Kasus Pengrajin Logam di Desa Ngingas Kecamatan Waru Kabuppaten Sidoarjo). Hal. 75-76.

Van-de-Ven (1995) Ruang dalam Arsitektur edisi ketiga, Gramedia Pustaka Utama, Jakarta. 